\title{
Implementasi Gaya Hidup Nazir untuk Hamba Tuhan yang Bergaya Hidup Hedonisme
}

yang Berdampak pada Pelayanannya

"Sambo Puang”

Institut Agama Kristen Negri Toraja ( IAKN ) Toraja

Jalan Poros Makale-Makassar KM 11,5, Buntu Tangti, Mengkendek, Kab. Tana Toraja

Sulawesi Selatan 91871

E-Mail: puangsambo@gmail.com

\begin{abstract}
Abstrak
Hamba Tuhan adalah seorang pelayan Tuhan didalam dunia ini untuk melayani umat-umat Tuhan. Hamba Tuhan harus tulus melayani umat Tuhan sebagai bentuk jawaban atas panggilan Allah terhadap dirinya. Oleh karna itu Hamba Tuhan harus menjadikan gaya hidup Nazir dalam menjalankan tugasnya. Tetapi masa sekarang ini buktinya kebanyakan Hamba Tuhan yang hidup dalam gaya hidup Hedonisme yaitu lebih mengutamakan hidup kesenangan dan tidak mau hidup susah dan bahkan melakukan pelayanan dengan semaunya saja atau tidak sesuai dengan Firman Tuhan. Gaya hidup Heonisme sangat berbahaya apabilah dianut oleh Hamba Tuhan baik bagi pelayanannya maupun dalam kehidupannya sehari karna ia akan melakukan berbagai cara untuk mendapatkan kesenangan itu. Aspek kehidupan manusia pada masa kini ikut berubah seiring dengan berjalannya zaman baik dipengaruhi oleh perkembangan teknologi yang semakin canggih yang membuat manusia yang ingin serba instan. Salah satunya yang berubah adalah pola gaya hidup. Gaya hidup yang paling menonjol sekarang ini adalah gaya hidup Hedonis. Bahkan gaya hidup ini juga ada Hamba Tuhan yang menganutnya.
\end{abstract}

Kata Kunci : Gaya Hidup Nazir, Hedonisme, Hamba Tuhan.

\section{Pendahuluan}

Dari masa kemasa gaya hidup manusia akan terus mengalami perubahan sesuai dengan tuntutan zaman diamana tehnologi yang semakin canggih. Dan buktinya sekarang dalam kehidupan masyarakat Indonesia pada zaman sekarang ini lebih cenderung terhadap 